Diterima: 29/09/2020, Direview: 29/01/2021, Diterbitkan: 30/04/2021

\title{
KARAKTERISTIK FISIKOKIMIA COOKIES DENGAN VARIASI TEPUNG SORGUM DAN PATI JAGUNG SERTA VARIASI MARGARIN DAN WHEY
}

\section{Physico-chemical Characteristics of Cookies in Different Level of Sorghum Flour, Corn Starch, Margarine, and Whey}

\author{
Rinda Lestari Rahayu*, Ahmad Zaki Mubarok' Nur Istianah \\ Jurusan Teknologi Hasil Pertanian, FTP Universitas Brawijaya \\ Jl. Veteran, Malang 65145 \\ *Penulis Korespondensi, Email: 98rindalestari@gmail.com
}

\begin{abstract}
ABSTRAK
Cookies dapat diformulasikan dari bahan baku lokal, misalnya tepung sorgum. Cookies sorgum berwarna gelap dan bertekstur keras sehingga perlu ditambahkan pati jagung untuk meningkatkan kecerahan dan kerenyahan. Penelitian bertujuan menganalisis pengaruh proporsi tepung sorgum : pati jagung dan proporsi margarin : whey terhadap karakteristik fisikokimia cookies. Penelitian dirancang dengan Rancangan Acak Kelompok Faktorial. Faktor I proporsi tepung sorgum : pati jagung (70:30; 50:50; 30:70) dan Faktor II proporsi margarin : whey (80:0; 70:10; 60:20 dalam satuan $\mathrm{g})$. Analisis data menggunakan Anova $(\alpha=0.05)$, BNT, DMRT, dan Derringer's Desirability Function. Hasil penelitian menunjukkan peningkatan proporsi tepung sorgum menyebabkan peningkatan kadar air, ALB, kemerahan, daya patah, dan kekerasan tetapi menyebabkan penurunan kecerahan, kekuningan, dan penyusutan berat. Cookies perlakuan terbaik adalah tepung sorgum $50 \%$ dan whey $10 \mathrm{~g}$, dengan kecerahan 57.1 , kemerahan 7.0 , kekuningan 21.57 , susut berat $18.0 \%$, daya patah $8.4 \mathrm{~N}$, kekerasan $6.7 \mathrm{~N}$, kadar air $2.7 \%$, dan ALB $0.2 \%$.
\end{abstract}

Kata kunci: Bubuk whey, Cookies, Pati jagung, Tepung sorgum

\section{ABSTRACT}

Cookies can be formulated from local raw material, such as sorghum flour. Sorghum produced dark and hard cookies, and required corn starch addition to increase lightness and decrease fracturability of cookies. This study aims to analyze the influence of sorghum flour: corn starch proportion and margarine : whey to the physico-chemical characteristics of cookies. This research was conducted by Factorial Randomized Complete Design consist of sorghum flour:corn starch proportion $(70: 30 ; 50: 50 ; 30: 70)$ and margarine:whey proportion (80:0; 70:10; 60:20). The data was analyzed using ANOVA ( $\alpha=0.05), L S D$, DMRT and Derringer's Desirability Function. The results showed that sorghum flour increase water content, free fatty acid, redness, fracturability and hardness, and decrease lightness, yellowness, and weight loss. The best cookies formulated from sorghum flour $50 \%$ and whey powder $10 \mathrm{~g}$ with water content $2.7 \%$, FFA $0.2 \%$, lightness 57.1 , redness 7.0 , yellowness 21.57 , weight loss $18.0 \%$, fracturability $8.4 \mathrm{~N}$, and hardness $6.7 \mathrm{~N}$.

Keywords: Cookies, Corn starch, Sorghum flour, Whey powder

\section{PENDAHULUAN}

Makanan ringan banyak diminati karena praktis dan beragam jenis, salah satunya adalah cookies. Bahan baku pembuatan cookies dan produk bakery lain didominasi oleh tepung terigu karena gluten dapat menghasilkan produk bertekstur kokoh dan mengembang. Akan tetapi konsumsi gluten berlebihan dapat menyebabkan penyakit seliak (Robert dan 
Pillow, 2010) dan gangguan hiperaktif pada penderita autis (Kira, 2014). Bahan baku tepung terigu, yaitu gandum (Triticum spp.), merupakan tanaman subtropis sehingga kebutuhan gandum Indonesia bergantung dari impor. Menurut BPS (2019), angka impor gandum di Indonesia meningkat per tahun dan pada tahun 2017 mencapai 11.43 juta ton (11.434.134.1 ton) dengan nilai CIF US\$2.647.824.900. Berdasarkan pertimbangan kesehatan dan tingginya impor gandum, maka diperlukan pengembangan produk bebas gluten dari bahan baku lokal, salah satunya tepung sorgum.

Sorgum mudah tumbuh di iklim tropis dan tahan kekeringan (BPTP, 2013). Substitusi tepung sorgum pada cookies dapat meningkatkan kadar protein, tetapi menyebabkan cookies berwarna gelap (Katresna, 2017). Substitusi tepung sorgum pada biskuit menyebabkan adonan mudah hancur, sulit dibentuk (Biljwan, 2019), dan lengket (Onyango et al., 2011). Oleh karena itu diperlukan pati jagung untuk membentuk adonan yang lembut dan kompak (Nurbaya, 2013) serta meningkatkan kecerahan cookies (Hazzizah dan Estiasih, 2013). Pembuatan cookies membutuhkan lemak cukup banyak sehingga menyebabkan cookies mudah tengik. Lemak juga menghasilkan tekstur yang lebih berpori sehingga cookies mudah menyerap air dan tekstur melunak (Sitanggang, 2017). Oleh karena itu diperlukan bahan yang dapat mencegah migrasi kelembaban dan mempertahankan kekokohan tekstur cookies selama penyimpanan, yaitu bubuk whey. Penambahan bubuk whey sebesar $5 \%$ dapat menurunkan laju perubahan aktivitas air $\left(A_{w}\right)$ cookies Amaretti selama penyimpanan karena adanya protein dan laktosa yang mengikat air (Secchi et al, 2011). Penambahan Whey Protein Concentrate meningkatkan kadar protein dan daya penerimaan tekstur secara sensoris, serta menyebabkan warna, $A_{w}$ dan tekstur instrumental cookies tetap stabil selama penyimpanan 15 hari (Marques et al., 2016). Oleh karena itu tujuan penelitian ini ialah menganalisis pengaruh proporsi tepung sorgum : pati jagung dan proporsi margarin : whey terhadap karakteristik fisikokimia cookies serta menentukan formulasi terbaik.

\title{
BAHAN DAN METODE
}

\section{Bahan}

Bahan baku yang digunakan antara lain tepung sorgum putih varietas pahat yang ditepungkan oleh CV Sedana Panen Sejahtera, Jombang, dan pati jagung bermerk dagang "Maizenaku". Bahan lain yang digunakan antara lain garam (Indomaret), gula halus (Rose Brand), margarin (Simas), baking powder (Koepoe Koepoe), whey powder (Darigold), dan telur. Bahan analisis yang digunakan antara lain PE, etanol 95\%, indikator PP 1\%, aquades, dan $\mathrm{NaOH} 1 \mathrm{~N}$.

\begin{abstract}
Alat
Alat yang digunakan adalah color reader, desikator (Nalgene), Universal Testing Machine spec Digital Force Gauge (ZP-200 N, Imada), oven listrik (WTC BINDER), timbangan analitik (M-310. Denver Instrument), timbangan analitik (M-310. Denver Instrument), shaker waterbath, shaker, erlenmeyer, gelas beaker, pipet tetes, mortar dan alu, pipet ukur, bulb, pengaduk kaca, gelas ukur, gelas beaker, tabung reaksi, buret, dan statif.
\end{abstract}

\section{Desain Penelitian}

Desain penelitian ini ialah Rancangan Acak Kelompok Faktorial. Faktor I adalah proporsi tepung sorgum : pati jagung $(70: 30 ; 50: 50 ; 30: 70)$ dan Faktor II proporsi margarin : whey $(80: 0 ; 70: 10 ; 60: 20 \mathrm{~g})$ serta diulang 3 kali.

\section{Tahapan Penelitian}

Pembuatan cookies diawali dengan pengadukan adonan creaming (margarin, sukrosa, telur, dan baking powder) selama 5 menit menggunakan mixer kecepatan sedang. Kemudian ditambahkan tepung sorgum, pati jagung, garam, dan bubuk whey, serta diaduk menggunakan spatula selama 5 menit. Setelah itu didiamkan selama 15 menit untuk resting. 
Adonan ditimbang $10 \mathrm{~g}$ dan dicetak dengan ukuran $6 \times 3 \mathrm{~cm}$ dan ketebalan $0.5 \mathrm{~cm}$. Lalu dioven selama 25 menit dengan suhu $150^{\circ} \mathrm{C}$ dan dianalisis.

\section{Analisis Data}

Analisis data yang dilakukan antara lain Anova, uji lanjut BNT (Beda Nyata Terkecil), dan DMRT (Duncan Multiple Range Test) pada taraf 5\%. Perlakuan terbaik ditentukan menggunakan metode Derringer Desirability Function.

\section{Prosedur Analisis}

Kadar air dianalisis dengan metode oven, yaitu menghancurkan cookies dengan mortar dan alu. Kemudian menimbang sampel sebanyak 2 gram dan diletakkan di cawan alumunium. Setelah itu dikeringkan dalam oven hingga tercapai berat konstan dan ditimbang setiap jam (AOAC, 2005). Kadar asam lemak bebas dianalisis dengan metode titrasi. Cookies yang telah dihancurkan, diekstrak lemaknya dengan Petroleum eter. Kemudian ekstrak lemak cookies disaring dan dimaserasi dengan pelarut etanol $96 \%$ netral bersuhu $70^{\circ} \mathrm{C}$ menggunakan shaker selama 30 menit. Setelah itu ditambahkan indikator PP sebanyak $2 \mathrm{ml}$, lalu dititrasi dengan $\mathrm{NaOH} 0.1 \mathrm{~N}$ sampai terbentuk larutan berwarna merah muda (BSN, 2011). Analisis penyusutan berat dilakukan dengan menimbang berat adonan dan berat cookies menggunakan timbangan analitik. Daya patah dan kekerasan dianalisis dengan Digital Force Gauge, yaitu dengan meletakkan cookies di penampang. Kemudian mesin dijalankan hingga tuas mematahkan atau menekan cookies. Tuas yang digunakan untuk uji kekerasan berbentuk memanjang vertikal dan mengerucut, sedangkan tuas untuk uji daya patah berbentuk persegi yang memanjang horisontal (Midayanto dan Yuwono, 2014). Uji warna dilakukan dengan metode CIELAB menggunakan color reader. Cookies diletakkan di dalam plastik PE transparan, kemudian sensor alat diarahkan pada permukaan cookies dan dilakukan pengujian. Diulangi untuk tiga sisi cookies yang berbeda (Kusuma et al, 2017).

\section{HASIL DAN PEMBAHASAN}

\section{Karakteristik Bahan Baku}

Karakteristik bahan baku diperoleh dari klaim produk, antara lain kadar protein, lemak, dan karbohidrat. Analisis uji yang dilakukan antara lain kadar air dan warna (L, a, b). karakteristik bahan baku pada Tabel 1.

Tabel 1. Karakteristik Bahan Baku

\begin{tabular}{lrrrr}
\hline & \multicolumn{2}{c}{ Tepung Sorgum } & \multicolumn{2}{c}{ Pati Jagung } \\
\cline { 2 - 5 } Parameter & $\begin{array}{c}\text { Hasil } \\
\text { Analisis/ } \\
\text { klaim }\end{array}$ & Literatur & $\begin{array}{c}\text { Hasil } \\
\text { Analisis/ } \\
\text { klaim }\end{array}$ & Literatur \\
\hline Kadar air (\%) & $11.46 \pm 0.11^{\mathrm{a}}$ & $9.20 \pm 0.04^{\mathrm{c}}$ & - & $8.97-10.08^{\mathrm{d}}$ \\
Protein (\%) & $12.50^{\mathrm{b}}$ & $8.29 \pm 0.09^{\mathrm{c}}$ & $1.00^{\mathrm{b}}$ & $0.67^{\mathrm{e}}$ \\
Lemak (\%) & $200^{\mathrm{b}}$ & $2.80 \pm 0.08^{\mathrm{c}}$ & - & $0.39^{\mathrm{e}}$ \\
Abu (\%) & - & $0.28 \pm 0.00^{\mathrm{c}}$ & - & $0.39^{\mathrm{e}}$ \\
Karbohidrat (\%) & $73.00^{\mathrm{b}}$ & $79.42 \pm 0.31^{\mathrm{c}}$ & $89.00^{\mathrm{b}}$ & $98.79^{\mathrm{e}}$ \\
\hline
\end{tabular}

Sumber: a [Hasil analisis], b [Klaim produk], c (Suprijadi, 2012), d (Suarni et al., 2013), e (Alam and Nurhaeni, 2008).

Berdasarkan Tabel 1. terdapat beberapa perbedaan karakteristik dengan literatur. Perbedaan tersebut dapat disebabkan karena perbedaan varietas tanaman (Sastrahidayat dan Hadiastono, 2011), perbedaan metode penanaman, kondisi lingkungan, genetik (Daryono dan Maryanto, 2018), metode penepungan (Asropi et al., 2019) dan metode ekstraksi pati (Alam dan Nurhaeni, 2008). 


\section{Karakteristik Cookies}

\section{a. Kadar Air}

Hasil uji Anova $(\alpha=0.05)$ menunjukkan adanya perbedaan nyata pada perlakuan proporsi margarin : whey. Berdasarkan Tabel 2. peningkatan proporsi whey menyebabkan peningkatan kadar air. Hal ini diduga karena whey mengandung protein dan laktosa yang mampu mengikat air sehingga menurunkan penguapan air ketika pengovenan. Hal yang sama dinyatakan oleh Stear (2012) bahwa protein memiliki gugus hidroksil. Hasil yang sama juga dilaporkan pada hasil penelitian pancake tanpa telur (Akshata et al., 2019) dan cookies Amaretti (Secchi et al., 2011). Peningkatan proporsi margarin menurunkan kadar air diduga karena lemak membentuk laminasi hidrofobik di sekeliling komponen adonan sehingga hidrasi tepung terhambat. Stear (2012) juga menyatakan bahwa lemak dapat mengintervensi ikatan polar. Hasil yang sama juga dikemukakan pada penelitian cookies gembili (Prameswari dan Estiasih, 2013), cookies uwi putih (Hazzizah dan Estiasih, 2013), dan cookies talas umbi kuning (Nurbaya, 2013).

Tabel 2. Kadar Air Cookies Akibat Proporsi Margarin : Whey

\begin{tabular}{cc}
\hline Margarin : Whey $(\mathbf{g})$ & Kadar Air $(\%)$ \\
\hline $80: 0$ & $2.08 \pm 0.09 \mathrm{c}$ \\
$70: 10$ & $2.62 \pm 0.16 \mathrm{~b}$ \\
$60: 20$ & $3.12 \pm 0.15 \mathrm{a}$ \\
\hline
\end{tabular}

\section{b. Kadar Asam Lemak Bebas}

Hasil Anova $(\alpha=0.05)$ menunjukkan terdapat perbedaan signifikan pada perlakuan proporsi tepung. Tabel 3. menunjukkan bahwa peningkatan proporsi tepung sorgum meningkatkan kadar ALB. Hal ini disebabkan tepung sorgum mengandung lemak $2.0 \%$ (Tabel 1.) dan lebih besar dibanding kadar lemak pati jagung sebesar $0.39 \%$ (Alam dan Nurhaeni, 2008). Peningkatan kadar lemak pada bahan dapat menyebabkan peningkatan hidrolisis lemak sehingga dihasilkan cookies dengan kadar ALB lebih tinggi. Hal ini didukung dengan pernyataan Gebreselassie dan Clifford (2016) bahwa tepung sorgum mengandung enzim lipase yang dapat mengkatalisis hidrolisis lemak.

Tabel 3 Kadar Asam Lemak Bebas Akibat Proporsi Tepung Sorgum : Pati Jagung

\begin{tabular}{cc}
\hline Tepung Sorgum : Pati Jagung (\%) & Kadar Asam Lemak Bebas (\%) \\
\hline $70: 30$ & $0.20 \pm 0.04 \mathrm{a}$ \\
$50: 50$ & $0.19 \pm 0.03 \mathrm{a}$ \\
$30: 70$ & $0.15 \pm 0.03 \mathrm{~b}$
\end{tabular}

Keterangan: Notasi berbeda menunjukkan perbedaan nyata $(\alpha=0.05)$

Hasil Anova $(\alpha=0.05)$ menunjukkan terdapat perbedaan signifikan pada perlakuan margarin : whey. Tabel 4. menunjukkan bahwa peningkatan proporsi margarin meningkatkan kadar ALB. Hal ini disebabkan kadar lemak margarin mencapai 80\% (Yuwono et al., 2017) dan lebih tinggi dibandingkan whey yang sebesar 1.00-1.50\% (Guo, 2019). Hidrolisis lemak yang menghasilkan asam lemak bebas diduga karena saat pengadukan terjadi kontak antara lemak, air, dan enzim lipase pada tepung sorgum. Menurut Gebreselassie and Clifford (2016) hidrolisis lemak terhenti ketika suhu mencapai $50^{\circ} \mathrm{C}$ karena enzim terinaktivasi. Hasil yang sama juga dikemukakan pada penelitian biskuit santang yang diperkaya dengan santan (Kumolontang, 2015), dan biskuit yang diperkaya dengan flaxseed (Rajiv et al, 2012).

Tabel 4. Kadar Asam Lemak Bebas Cookies Akibat Proporsi Margarin : Whey

\begin{tabular}{cc}
\hline Margarin : Whey $(\mathbf{g})$ & Kadar Asam Lemak Bebas (\%) \\
\hline $80: 0$ & $0.21 \pm 0.03 \mathrm{a}$ \\
$70: 10$ & $0.18 \pm 0.03 \mathrm{~b}$ \\
$60: 20$ & $0.15 \pm 0.02 \mathrm{c}$ \\
\hline
\end{tabular}

Keterangan: Notasi berbeda menunjukkan perbedaan nyata $(\alpha=0.05)$ 


\section{c. Warna}

Kecerahan

Tabel 5. menunjukkan peningkatan proporsi tepung sorgum menyebabkan penurunan intensitas kecerahan $\left(\mathrm{L}^{*}\right)$ pada cookies. Hal ini diduga terjadi karena tepung sorgum mengandung protein yang lebih tinggi dibandingkan dengan pati jagung sehingga reaksi Maillard berlangsung lebih signifikan. Berdasarkan klaim bahan baku pada Tabel 3.1. tepung sorgum mengandung protein $12.5 \%$ sedangkan protein pati jagung sebesar $0.67 \%$. Hasil yang sama juga dikemukakan pada penelitian biskuit (Alfiana, 2016) dan crumb roti (Jafari et al., 2017).

Tabel 5. Kecerahan Cookies Akibat Proporsi Tepung Sorgum : Pati Jagung

$\begin{array}{cc}\text { Tepung Sorgum : Pati Jagung (\%) } & \text { Kecerahan }\left(\mathbf{L}^{*}\right) \\ 70: 30 & 55.00 \pm 2.10 \mathrm{~b} \\ 50: 50 & 57.16 \pm 3.55 \mathrm{ab} \\ 30: 70 & 59.10 \pm 2.84 \mathrm{a}\end{array}$

Keterangan: Notasi berbeda menunjukkan perbedaan nyata $(\alpha=0.05)$

Berdasarkan Tabel 6. peningkatan intensitas kecerahan $\left(L^{*}\right)$ terjadi jika proporsi margarin meningkat dan proporsi whey menurun. Hal ini diduga karena whey mengandung protein sebesar $11.0-14.5 \%$ dan lebih tinggi daripada margarin, serta kandungan laktosa sebesar 63.0-75.0\% pada whey (Guo, 2019). Protein dan laktosa pada whey berperan dalam reaksi Maillard sebagai penyedia gugus amino dan gula reduksi sehingga kecerahan $\left(L^{*}\right)$ cookies menurun. Hasil serupa juga dikemukakan pada penelitian cookies uwi putih (Hazzizah dan Estiasih, 2013), cookies tepung amaranth dan chickpea (Sarabhai, 2017) dan cookies Amaretti (Secchi et al., 2011).

Tabel 6. Kecerahan Cookies Akibat Proporsi Margarin : Whey

\begin{tabular}{cc}
\hline Margarin : Whey $\mathbf{( g )}$ & Kecerahan $\left(\mathbf{L}^{*}\right)$ \\
\hline $80: 0$ & $59.91 \pm 2.74 \mathrm{a}$ \\
$70: 10$ & $57.05 \pm 1.60 \mathrm{~b}$ \\
$60: 20$ & $54.30 \pm 1.98 \mathrm{C}$ \\
\hline
\end{tabular}

Keterangan: Notasi berbeda menunjukkan perbedaan nyata $(\alpha=0.05)$

\section{Kemerahan}

Hasil Anova menunjukkan adanya interaksi antara kedua faktor. Pada Tabel 7, intensitas kemerahan meningkat dengan peningkatan proporsi tepung sorgum dan whey. Hal ini diduga terjadi karena reaksi Maillard dan karamelisasi.

Tabel 7. Kemerahan Cookies Akibat Interaksi Kedua Faktor

\begin{tabular}{|c|c|c|}
\hline \multicolumn{2}{|c|}{ Perlakuan } & \multirow[b]{2}{*}{$\begin{array}{c}\text { Rata-Rata Intensitas } \\
\text { Kemerahan }\left(a^{*}\right)\end{array}$} \\
\hline $\begin{array}{c}\text { Proporsi Tepung Sorgum : } \\
\text { Pati jagung (\%) }\end{array}$ & $\begin{array}{l}\text { Proporsi Margarin } \\
\text { : Whey }(\mathrm{g})\end{array}$ & \\
\hline $70: 30$ & $\begin{array}{l}80: 0 \\
70: 10 \\
60: 20\end{array}$ & $\begin{array}{l}6.43 \pm 0.42 \mathrm{~b} \\
7.92 \pm 0.81 \mathrm{de}\end{array}$ \\
\hline $50: 50$ & $\begin{array}{l}80: 0 \\
70: 10 \\
60: 20\end{array}$ & $\begin{array}{l}3.41 \pm 0.35 \mathrm{a} \\
7.05 \pm 0.40 \mathrm{bcd} \\
8.01 \pm 0.64 \mathrm{de}\end{array}$ \\
\hline $30: 70$ & $\begin{array}{l}80: 0 \\
70: 10 \\
60: 20\end{array}$ & $\begin{array}{l}3.15 \pm 0.53 \mathrm{a} \\
6.82 \pm 0.89 \mathrm{bc} \\
7.64 \pm 0.21 \mathrm{cde}\end{array}$ \\
\hline
\end{tabular}

Keterangan: Notasi berbeda menunjukkan perbedaan nyata $(\alpha=0.05)$

Tepung sorgum dan whey mengandung protein sehingga saling bersinergis dalam reaksi Maillard. Laktosa pada whey juga berkontribusi mempercepat reaksi Maillard dan 
karamelisasi karena laktosa merupakan gula sederhana yang lebih reaktif dibandingkan pati. Warna coklat yang terbentuk dapat diinterpretasikan sebagai kemerahan karena menurut Wijaya and Anastasya (2019) warna cokelat merupakan warna tersier yang dihasilkan dari perpaduan warna jingga dan ungu. Warna jingga merupakan warna sekunder yang tersusun atas warna merah dan kuning, sedangkan ungu merupakan perpaduan antara merah dan biru. Hasil yang sama juga dikemukakan pada penelitian cookies talas umbi kuning (Nurbaya, 2013), biskuit (Alfiana, 2016), dan cookies terigu (Wani et al., 2015).

\section{Kekuningan}

Hasil Anova menunjukkan perlakuan proporsi tepung sorgum : pati jagung berbeda signifikan. Berdasarkan Tabel 8, intensitas kekuningan meningkat akibat peningkatan proporsi pati jagung. Hal ini diduga disebabkan karena pati jagung memiliki warna yang lebih cerah dibandingkan tepung sorgum sehingga menghasilkan produk berwarna cerah. Menurut Rasyid dan Zainuddin (2019), pati jagung mengandung pigmen zeaxanthin, lutein, dan betakaroten yang berkontribusi terhadap warna kuning. Hasil yang sama juga dikemukakan pada penelitian biskuit (Alfiana, 2016) dan cookies tepung gembili (Prameswari dan Estiasih, 2013).

Tabel 8. Intensitas Kekuningan $\left(b^{*}\right)$ Cookies Akibat Proporsi Tepung Sorgum : Pati Jagung

\begin{tabular}{cc} 
Tepung Sorgum : Pati Jagung (\%) & Intensitas Kekuningan (b*) \\
\hline $70: 30$ & $21.22 \pm 0.39 \mathrm{~b}$ \\
$50: 50$ & $21.82 \pm 1.27 \mathrm{~b}$ \\
$30: 70$ & $24.71 \pm 0.94 \mathrm{a}$ \\
\hline
\end{tabular}

Keterangan: Notasi berbeda menunjukkan perbedaan nyata $(\alpha=0.05)$

\section{d. Penyusutan berat}

Hasil Anova menunjukkan perlakuan proporsi tepung sorgum : pati jagung berbeda signifikan. Penyusutan berat cookies dipengaruhi oleh kandungan protein dan amilopektin. Tepung sorgum mengandung protein dan amilopektin lebih tinggi dibanding pati jagung, sehingga memiliki gugus hidroksil lebih banyak yang meningkatkan kemampuan mengikat air. Hal ini didukung dengan pernyataan Foschia et al. (2017) bahwa protein pada bahan dapat mencegah penguapan air karena memiliki ikatan hidrogen, sehingga dihasilkan densitas produk yang lebih tinggi. Hasil yang sama juga dikemukakan pada penelitian kue (Zhong et al., 2018), roti sorgum (Onyango et al., 2011), dan biskuit (Conforti et al., 2012).

Tabel 9. Persen Penyusutan Berat Cookies Akibat Proporsi Tepung Sorgum : Pati Jagung

\begin{tabular}{cr}
\hline Tepung Sorgum : Pati Jagung (\%) & Penyusutan Bera \\
\hline $70: 30$ & $17.07 \pm 1.05 \mathrm{a}$ \\
$50: 50$ & $18.04 \pm 1.48 \mathrm{~b}$ \\
$30: 70$ & $18.98 \pm 1.43 \mathrm{C}$
\end{tabular}

Keterangan: Notasi berbeda menunjukkan perbedaan nyata $(\alpha=0.05)$

Tabel 10 menunjukkan peningkatan proporsi whey menyebabkan penurunan baking loss. Hal ini terjadi karena whey mengandung protein yang memiliki gugus hidroksil dan mampu mengikat air dengan kapasitas tertentu atau Water Holding Capacity (WHC). Whey dapat menurunkan baking loss karena adanya laktosa yang merupakan disakarida. Gula merupakan bahan yang dapat mengikat air sehingga menurunkan air bebas. Air yang terikat sukar menguap ketika dioven. Menurut Guo (2019) bubuk whey mengandung protein sebesar $11.0-14.5 \%$ dan laktosa $63.0-75.0 \%$, sedangkan menurut Yuwono et al. (2017) margarin tersusun atas $80 \%$ lemak, $20 \%$ air, dan tidak mengandung protein. Penelitian lain yang juga mengemukakan bahwa penambahan whey dan bahan substitusi lemak lain dapat menurunkan baking loss pada roti terigu (Wronkowska et al., 2015) dan biskuit sorgum (Omoba dan Omogbemile, 2013). 
Tabel 10. Rata-Rata \% Penyusutan Berat Cookies Akibat Proporsi Margarin : Whey

\begin{tabular}{cr}
\hline Margarin : Whey $\mathbf{( g )}$ & Penyusutan Berat \\
\hline $80: 0$ & $19.31 \pm 0.99 \mathrm{c}$ \\
$70: 10$ & $18.02 \pm 0.97 \mathrm{~b}$ \\
$60: 20$ & $16.76 \pm 0.62 \mathrm{a}$
\end{tabular}

Keterangan: Notasi berbeda menunjukkan perbedaan nyata $(\alpha=0.05)$

\section{e. Daya patah}

Tabel 11. menunjukkan peningkatan proporsi tepung sorgum menyebabkan peningkatan daya patah cookies. Peningkatan dikarenakan tepung sorgum mengandung protein dan amilopektin yang lebih tinggi dibandingkan pati jagung sehingga dihasilkan struktur cookies yang lebih kokoh. Penyebab lain adalah ukuran tepung sorgum cukup besar, yaitu 80 mesh sehingga memerlukan waktu yang lama untuk hidrasi. Hal ini didukung dengan pernyataan Onyango et al (2011) bahwa partikel endosperma dan bran sorgum tidak dapat membentuk ikatan yang kuat sehingga tepung sorgum tidak mampu mengembang dan mempertahankan gas yang terbentuk ketika pengovenan. Partikel tersebut mengalami deformasi, menyusut, membentuk struktur yang padat dan kokoh sehingga meningkatkan daya patah. Hasil yang sama juga dikemukakan pada penelitian penelitian biskuit terigu (Rosniar, 2016), cookies talas umbi kuning (Nurbaya, 2013), dan cookies gembili (Prameswari dan Estiasih, 2013).

Tabel 11. Rata-Rata Daya Patah Cookies Akibat Proporsi Tepung Sorgum : Pati Jagung

$\begin{array}{r}\text { Tepung Sorgum } \\ \hline \begin{array}{r}70: 30 \\ 50: 50 \\ 30: 70\end{array}\end{array}$
Daya Patah (N)

$50: 50$

$9.30 \pm 1.86 \mathrm{a}$

$8.08 \pm 1.78 b$

$7.27 \pm 1.98 b$

Keterangan: Notasi berbeda menunjukkan perbedaan nyata $(\alpha=0.05)$

Tabel 12. menunjukkan daya patah cookies meningkat dengan peningkatan proporsi whey. Hal ini disebabkan karena penambahan whey meningkatkan kadar protein dan laktosa pada cookies. Protein berperan sebagai pengikat air dan komponen bahan (pengemulsi) sehingga dihasilkan cookies yang lebih kokoh. Sementara laktosa berperan mengikat air sehingga mengurangi penguapan air saat dioven dan mempertahankan kekokohan tekstur. Hal ini sejalan dengan yang dikemukakan oleh Estiasih et al. (2016) bahwa bahan yang memiliki daya ikat tinggi dapat meningkatkan kekokohan tekstur sehingga daya patah meningkat. Margarin melubrikasi komponen adonan cookies sehingga menghambat hidrasi dan meningkatkan kerenyahan cookies. Hasil yang sama juga dikemukakan bahwa peningkatan rasio margarin menurunkan daya patah cookies uwi putih (Hazzizah dan Estiasih, 2013) dan cookies talas umbi kuning (Nurbaya, 2013). Sementara penggunaan whey sebagai substitut lemak meningkatkan daya patah cookies (Sarabhai dan Prabhasankar, 2015) dan roti (Paul et al., 2019).

Tabel 12. Rata-Rata Daya Patah Cookies Akibat Proporsi Margarin : Whey

\begin{tabular}{cc}
\hline Margarin : Whey $(\mathbf{g})$ & Daya Patah $(\mathbf{N})$ \\
$80: 0$ & $6.29 \pm 0.92 \mathrm{c}$ \\
$70: 10$ & $8.37 \pm 1.37 \mathrm{~b}$ \\
$60: 20$ & $9.99 \pm 0.81 \mathrm{a}$
\end{tabular}

Keterangan: Notasi berbeda menunjukkan perbedaan nyata $(\alpha=0.05)$

\section{f. Kekerasan}

Tabel 13. menunjukkan peningkatan proporsi tepung sorgum menyebabkan peningkatan kekerasan cookies. Peningkatan tersebut diduga disebabkan karena kadar 
protein dan amilopektin pada tepung sorgum. Protein dan amilopektin memiliki gugus hidroksil sehingga menghasilkan cookies yang lebih kokoh dan keras. Sementara itu, pati jagung memiliki kadar amilosa yang lebih besar sehingga sukar mempertahankan air yang diikat. Akibatnya, perlakuan dengan proporsi pati jagung lebih tinggi memiliki nilai kekerasan lebih kecil. Hasil ini sesuai dengan penyataan Estiasih et al (2016) bahwa pati dapat membentuk ikatan kohesif dan melarutkan partikel endosperma dan bran sorgum sehingga dapat terbentuk gel pati yang lebih seragam dan tekstur lembut. Hasil yang sama juga dikemukakan pada penelitian biskuit terigu (Saputro et al, 2017), roti (Onyango et al, 2011), dan cookies uwi putih (Hazzizah dan Estiasih, 2013).

Tabel 13. Rata-Rata Kekerasan Cookies Akibat Proporsi Tepung Sorgum : Pati Jagung

\begin{tabular}{cc}
\hline Tepung Sorgum $:$ Pati Jagung (\%) & Kekerasan $(\mathbf{N})$ \\
$70: 30$ & $8.04 \pm 1.19 \mathrm{a}$ \\
$50: 50$ & $7.01 \pm 1.83 \mathrm{~b}$ \\
$30: 70$ & $6.58 \pm 1.80 \mathrm{~b}$
\end{tabular}

Keterangan: Notasi berbeda menunjukkan perbedaan nyata $(\alpha=0.05)$

Tabel 14. menunjukkan peningkatan proporsi whey menyebabkan peningkatan kekerasan cookies. Hal ini diduga karena whey mengandung protein dan laktosa yang dapat mengikat air dan meningkatkan kekokohan tekstur. Margarin dapat menurunkan kekerasan cookies karena berperan sebagai lubrikasi di sekeliling komponen bahan. Lubrikasi tersebut menghasilkan tekstur yang lebih lunak. Hal ini didukung dengan pernyataan Marques et al. (2016) bahwa laktosa dapat mengalami rekristalisasi setelah pengovenan sehingga dihasilkan tekstur yang keras. Menurut Dian (2018), tekstur lunak diperoleh karena margarin menciptakan kondisi hidrofobik yang menghambat penyerapan air dan memerangkap gas ketika pengovenan. Hasil yang sama juga dikemukakan pada penelitian roti multigrain (Paul et al., 2019), cookies amaranth dan kacang arab atau chickpea (Sarabhai dan Prabhasankar, 2015), dan cookies terigu (Wani et al, 2015) dan (Gani et al., 2015).

Tabel 14. Rata-Rata Kekerasan Cookies Akibat Proporsi Margarin : Whey

\begin{tabular}{cc}
\hline Margarin : Whey $\mathbf{( g )}$ & Kekerasan $(\mathbf{N})$ \\
\hline $80: 0$ & $5.74 \pm 1.17 \mathrm{c}$ \\
$70: 10$ & $6.97 \pm 0.65 \mathrm{~b}$ \\
$60: 20$ & $8.92 \pm 0.47 \mathrm{a}$
\end{tabular}

Keterangan: Notasi berbeda menunjukkan perbedaan nyata $(\alpha=0.05)$

\section{g. Penentuan Perlakuan Terbaik}

Perlakuan terbaik ditentukan menggunakan persamaan Derringer Desirability Function. Parameter kadar air dan kadar ALB dihitung dengan persamaan minimum desirability. Batas maksimal kadar air 5\% dan kadar asam lemak bebas 1\% sesuai SNI Biskuit 2973:2011. Parameter warna ( $L, a, b)$, susut berat, daya patah, dan kekerasan ditentukan dengan persamaan targeted desirability yang dibandingkan dengan kontrol. Hasil perhitungan persamaan Derringer ditunjukkan pada Tabel 15.

Tabel 15. Perhitungan Persamaan Derringer

\begin{tabular}{ccccccccccc}
\hline $\begin{array}{c}\text { Sam- } \\
\text { pel }\end{array}$ & $\mathbf{L}$ & $\mathbf{a}$ & $\mathbf{b}$ & $\begin{array}{c}\text { Susut } \\
\text { Berat }\end{array}$ & $\begin{array}{c}\text { Daya } \\
\text { Patah }\end{array}$ & Kekerasan & $\begin{array}{c}\text { Kadar } \\
\text { Air }\end{array}$ & ALB & D & $\begin{array}{c}\text { Ra } \\
\text { nk }\end{array}$ \\
\hline L1T1 & 0.58 & 0.81 & 0.19 & 0.46 & 0.48 & 0.91 & 0.83 & 0.84 & 0.58 & 4 \\
L1T2 & 0.45 & 0.54 & 0.25 & 0.76 & 0.97 & 0.70 & 0.66 & 0.90 & 0.61 & 3 \\
L1T3 & 0.19 & 0.34 & 0.18 & 0.92 & 0.38 & 0.14 & 0.50 & 0.93 & 0.36 & 7 \\
L2T1 & 0.94 & 0.08 & 0.38 & 0.22 & 0.27 & 0.33 & 0.83 & 0.88 & 0.38 & 6 \\
L2T2 & $\mathbf{0 . 6 0}$ & $\mathbf{0 . 9 5}$ & $\mathbf{0 . 2 4}$ & $\mathbf{0 . 5 1}$ & $\mathbf{0 . 7 0}$ & $\mathbf{0 . 9 7}$ & $\mathbf{0 . 6 7}$ & $\mathbf{0 . 8 9}$ & $\mathbf{0 . 6 4}$ & $\mathbf{1}$ \\
L2T3 & 0.28 & 0.48 & 0.16 & 0.80 & 0.96 & 0.28 & 0.54 & 0.94 & 0.47 & 5 \\
L3T1 & 0.83 & 0.02 & 0.56 & 0.06 & 0.12 & 0.10 & 0.88 & 0.91 & 0.22 & 8 \\
L3T2 & 0.74 & 0.90 & 0.54 & 0.28 & 0.43 & 0.85 & 0.74 & 0.94 & 0.63 & 2 \\
L3T3 & 0.55 & 0.73 & 0.41 & 0.62 & 0.90 & 0.46 & 0.59 & 0.97 & 0.63 & 2 \\
\hline
\end{tabular}




\section{SIMPULAN}

Peningkatan proporsi tepung sorgum berpengaruh nyata terhadap penurunan intensitas kecerahan $\left(L^{*}\right)$ dan intensitas kekuningan $\left(b^{*}\right)$, serta peningkatan intensitas kemerahan $\left(\mathrm{a}^{*}\right)$, berat, daya patah, kekerasan, dan asam lemak bebas. Peningkatan proporsi whey berpengaruh nyata terhadap penurunan intensitas kecerahan $\left(L^{*}\right)$ dan asam lemak bebas, serta peningkatan intensitas kemerahan $\left(a^{*}\right)$, berat, daya patah, kekerasan, dan kadar air. Perlakuan terbaik yang menghasilkan cookies dengan karakteristik menyerupai kontrol (tepung terigu) adalah proporsi tepung sorgum $50 \%$ dan proporsi margarin : whey sebesar 70:10. Hal ini membuktikan bahwa pati jagung dan bubuk whey mampu memperbaiki karakteristik cookies sorgum.

\section{DAFTAR PUSTAKA}

Akshata, B., Indrani, D., \& Prabhasankar, P. (2019). Effects of Ingredients and Certain Additives on Rheological and Sensory Characteristics of Gluten-Free Eggless Pancake. Journal of Food Processing and Preservation 43, 1-9.

Alam, N., \& Nurhaeni. (2008). Komposisi Kimia dan Sifat Fungsional Pati Jagung Berbagai Varietas yang Diekstrak dengan Pelarut Natrium Bikarbonat. Agroland: Jurnal IImuIImu Pertanian 15(2), 89-94.

Alfiana, T. A. (2016). Pengaruh Substitusi Tepung Sorgum Tanpa Sosoh terhadap Warna dan Daya Patah Biskuit. Skripsi. Universitas Muhammadiyah Surakarta. Surakarta.

AOAC. (2005). Official Methods of Analysis: Association of Official Analytic Chemists. Washington DC: Benjamin Franklin Station.

Asropi, A., Bintoro, N., Karyadi, J.N.W., Rahayoe, S., \& Saputro, A.D. (2019). Kinetika Perubahan Sifat Fisik dan Kadar Tanin Biji Sorgum (Sorghum Bicolor L.) selama Perendaman. Agritech 39, 222-233.

Biljwan, M., Naik, B., Sharma, D., Singh, A., \& Kumar, V. (2019). Recent Development in Dough Based Bakery Products: A Mini Review. The Pharma Innovation Journal. 8, 654-658.

BPS. (2019). Impor Biji Gandum dan Meslin Menurut Negara Asal Utama, 2010-2017. 30 Oktober 2019 Ed. Jakarta: Badan Pusat Statistik.

BPTP. (2013). Sorgum: Kandungan Tinggi, Kaya Manfaat, Dukung Gluten Free Diet. 9 Januari 2013 Ed. Jakarta: Balai Pengkajian Teknologi Pertanian.

BSN. (2011). Biskuit SNI 2973:2011. Jakarta: Badan Standarisasi Nasional.

Conforti, P. A., Yamul., D. K. \& Lupano., C. E. (2012). Influence of Milk, Corn Starch, and Baking Conditions on The Starch Digestibility, Gelatinization, and Fracture Stress of Biscuits. Journal of Cereal Chemical 89 (4), 205-210.

Daryono, B. S. \& Maryanto, S. D. (2018). Keanekaragaman dan Potensi Sumber Daya Genetik Melon. Yogyakarta: UGM Press.

Dian, N. L. H. M. (2018). Palm Oil and Palm Kernel Oil: Versatile Ingredients for Food Applications. Journal of Oil Palm Research 29 (4), 487-511.

Foschia, M., Horstmann, S. W., Arendt, E. K. \& Zannini, E. (2017). Legumes as Functional Ingredients in Gluten-Free Bakery and Pasta Products. Food Science and Technology 8, 75-96.

Gani, A., Broadway, A., Ahmad, M., Ashwar, B. A., Wani, A. A., Wani, S. M., Masoodi, F. \& Khatkar, B. S. (2015). Effect of Whey and Casein Protein Hydrolysates on Rheological, Textural and Sensory Properties of Cookies. Journal of Food Science and Technology 52, 5718-5726.

Gebreselassie, E. \& Clifford, H. (2016). Oxidative Stability and Shelf Life of Foods Containing Oils and Fats. London: Elsevier.

Guo, M. (2019). Whey Protein Production, Chemistry, Functionality, and Applications. Hoboken: Wiley. 
Hazzizah, H. \& Estiasih, T. (2013). Karakteristik Cookies Umbi Inferior Uwi Putih (Kajian Proporsi Tepung Uwi: Pati Jagung dan Penambahan Margarin). Jurnal Pangan dan Agroindustri 1, 138-147.

Jafari, M., Koocheki, A., \& Milani, E. (2017). Effect of extrusion cooking of sorghum flour on rheology, morphology and heating rate of sorghum-wheat composite dough. Journal of Cereal Science, 77, 49-57. doi:10.1016/j.jcs.2017.07.011

Katresna, N. P. (2017). Pengaruh Subtitusi Tepung Modifikasi Sorgum (Shorgum Bicolor L.) dan Tepung Terigu dengan Penambahan Bekatul Beras (Oryzae Sativa L.) terhadap Karakteristik Cookies. Skripsi. Universitas Pasundan. Bandung.

Kira, C. S. (2014). Autism Spectrum Disorder: The Complete Guide To Understanding Autism. Perigee. New York City.

Kumolontang, N. (2015). Pengaruh Penggunaan Santan Kelapa dan Lama Penyimpanan terhadap Kualitas "Cookies Santang”. Jurnal Penelitian Teknologi Industri 7 (2), 69-79.

Kusuma, T. S., Kurniawati, A. D., Rahmi, Y., Rusdan, I. H., Widyanto, R. M. \& Santoso, S. (2017). Pengawasan Mutu Makanan. Malang: Universitas Brawijaya Press.

Marques, G. D. A., Jose, J. F. B. D. S., Silva, D. A. \& Silva, E. M. M. D. (2016). Whey Protein as A Substitute for Wheat in The Development of No Added Sugar Cookies. Food Science and Technology 67, 118-126.

Midayanto, D. N. \& Yuwono, S. S. (2014). Penentuan Atribut Mutu Tekstur Tahu untuk Direkomendasikan sebagai Syarat Tambahan dalam Standar Nasional Indonesia. Jurnal Pangan dan Agroindustri 2 (4), 259-267.

Nurbaya, S. (2013). Pemanfaatan Talas Berdaging Umbi Kuning (Colocasia Esculenta (L.) Schott) dalam Pembuatan Cookies (Kajian Rasio Tepung Talas: Pati Jagung dan Tingkat Penambahan Margarin). Skripsi. Malang: Universitas Brawijaya.

Omoba, O. \& Omogbemile, A. (2013). Physicochemical Properties of Sorghum Biscuits Enriched with Defatted Soy Flour. British Journal of Applied Science and Technology 3 (4), 1246-1256.

Onyango, C., Mutungi., C., Unbehend., G. \& Lindhauer, M. G. (2011). Modification of Gluten Free Sorghum Batter and Bread Using Maize, Potato, Cassava Or Rice Starch. Food Science and Technology 44, 681-686.

Paul, S., Kulkarni., S. P. \& Rao, K. J. (2019). Utilisation of Concentrated Whey in The Production of Multigrain Bread: Optimisation of Solid Levels in Concentrated Whey and Temperatures of Baking. International Food Research Journal 26 (2), 599-606.

Prameswari, R. D. \& Estiasih, T. (2013). Pemanfaatan Tepung Gembili (Dioscorea Esculenta L.) dalam Pembuatan Cookies. Jurnal Pangan dan Agroindustri 1, 115-128.

Rajiv, J., Indrani, D., Prabhasankar, P. \& Rao, G. V. (2012). Rheology, Fatty Acid Profile and Storage Characteristics of Cookies as Influenced by Flax Seed (Linum Usitatissimum). Journal of Food Science and Technology 49 (5), 587-593.

Rasyid, N. P. \& Zainuddin, A. (2019). Pemanfaatan Pati Jagung Termodifikasi Teknik Microwave pada Mie Jagung. Jurnal Teknologi Pertanian 9 (1), 11-17.

Roberts, A. G. \& Pillow, C. (2010). The Gluten-Free Good Health Cookbook: The Delicious Way To Strengthen Your Immune System and Neutralize Inflammation. Evanston: Agate Publishing.

Rosniar, M. (2016). Perbedaan Tingkat Kekerasan dan Daya Terima Biskuit dari Tepung Sorgum Yang Disosoh dan Tidak Disosoh. Skripsi. Universitas Muhammadiyah Surakarta. Surakarta.

Saputro, S. B., Karyantina, M. \& Suhartatik, N. (2017). Karakteristik Biskuit dengan Variasi Substitusi Tepung Sorgum (Sorghum Bicolor L.) dan Ekstrak Jahe (Zingiber Officinale Rosch). Jurnal Teknologi dan Industri Pangan 2 (2), 89-95.

Sarabhai, S. \& Prabhasankar, P. (2015). Influence of Whey Protein Concentrate and Potato Starch on Rheological Properties and Baking Performance on Indian Water Chestnut Flour Based Gluten Free Cookie Dough. Journal of Food Science and Technology 63 (2), 1301-1308.

Sastrahidayat, I. R. \& Hadiastono, T. (2011). Tanaman Kentang dan Pengendalian Hama Penyakitnya. Universitas Brawijaya Press. Malang. 
Secchi, N., Stara, G., Anedda, R., Campus, M., Piga, A., Roggio, T. \& Catzeddu, P. (2011). Effectiveness of Sweet Ovine Whey Powder in Increasing The Shelf Life of Amaretti Cookies. Lwt-Food Science and Technology 44 (4), 1073-1078.

Sitanggang, A. B. (2017). Faktor Kerusakan Produk Bakeri dan Pengendaliannya. Food Review Indonesia 12 (2), 40-44.

Stear, C. A. (2012). Handbook of Breadmaking Technology. New York City: Springer Science and Business Media.

Wani, S. H., Gull, A., Allaie, F. \& Safapuri, T. A. (2015). Effects of Incorporation of Whey Protein Concentrate on Physicochemical, Texture, and Microbial Evaluation of Developed Cookies. Cogent Food \& Agriculture 1 (1).

Wijaya, Y. \& Anastasya, S. (2019). Teknik Mewarna Menggunakan Cat Air. Bantul: Alaf Media.

Wronkowska, M., Jadacka, M., Smieta, M. S., Zander, L., Dajnowiec, F., Banaszczyk, P., Jelinski, T. \& Szmatowicz, B. (2015). Acid Whey Concentrated by Ultrafiltration A Tool for Modelling Bread Properties. Food Science and Technology 61, 172-176.

Yuwono, S. S., Waziiroh, E. \& Putri, W. D. R. (2017). Teknologi Pengolahan Pangan Hasil Perkebunan. Malang: Universitas Brawijaya Press.

Zhong, Y., Zhu, H., Liang, W., Li, X., Liu, L., Zhang, X., Yue, H., Xue, J., Liu, X. \& Guo, D. (2018). High Amylose Starch as A New Ingredient to Balance Nutrition and Texture of Food. Journal of Cereal Science. 81, 8-14. 